\title{
Modeling Private Investment Behavior in Nigeria: A Cointegration Approach
}

\author{
Victor E. Oriavwote ${ }^{1} \&$ Dickson O. Oyovwi \\ ${ }^{1} \mathrm{PhD}$, Department of Economics and Development Studies, Federal University, Otuoke, Bayelsa State, Nigeria \\ ${ }^{2} \mathrm{PhD}$, Department of Economics, College of Education, Warri, Delta State, Nigeria \\ Correspondence: Victor E. Oriavwote, PhD, Department of Economics and Development Studies, Federal University, \\ Otuoke, Bayelsa State, Nigeria. Tel: 234- 080-3581-4123. E-mail: oriavwote40@yahoo.com
}

Received: April 14, 2013

Accepted: May 22, 2013

Online Published: May 31, 2013

doi:10.5430/afr.v2n3p14

URL: http://dx.doi.org/10.5430/afr.v2n3p14

\begin{abstract}
This study was aimed at investigating the behaviour of private investment in Nigeria. Using data covering the period between 1980 and 2011, the result of the parsimonious ECM indicates that the huge government expenditure on infrastructure has been beneficial to private investors in Nigeria. The result also indicates that private investment has been influenced by the international competitiveness of Nigeria as indicated by the significance of the Real Effective Exchange Rate. The high rate of inflation has however been detrimental to the development of private investment in Nigeria. The Johansen cointegration test supports the existence of a long run relationship among the variables and the negatively signed and significant ECM insinuates a satisfactory speed of adjustment. Government should thus intensify efforts to tackle the high rate of inflation and further increase the competitiveness of the economy.
\end{abstract}

Keywords: Private investment, Real effective exchange rate, Parsimonious ECM, Cointegration and the Nigerian Economy

\section{Introduction}

Improving private investment has been at the forefront of different fiscal and monetary strategies in Nigeria. The Structural Adjustment Programme (SAP) and the National Economic Empowerment and Development Strategies (NEEDS) were both premised on the development of private investment designed with the neoclassical paradigm. However, the country's enthusiasm with the strategies gradually lost momentum primarily because of failure to deliver the dividend of private investment driven economic growth. Despite structural reforms, the Nigerian economy continues to face a variety of problems. These problems include low level of savings and investment, high rate of inflation, high level of unemployment and extreme poverty. Major investment indicators support this. For example, private investment declined from 12.3 percent of GDP in 1991 to 8.3 percent of GDP in 1992. Private investment increased to 12.5 percent in 1993 and 16.0 percent in 1999 before declining to 10.7 percent in 2000. Between 2001 and 2005, the ratio averaged 13.0 percent (Bakare, 2011). As a component of overall demand, private investment has an impact on the level of aggregate demand because it has the highest level of fluctuation compared to more stable household consumption and public expenditure. Thus, a slowdown in investment is translated into a slowdown in growth (Sosthene, 2010). In addition, since private investment involves the accumulation of productive capacities, it determines the productive capacity of the economy as well as the manpower utilized in making the capacity to be operational. An increase in private investment over time helps to sustain the cycle of economic growth. Through the pursuit of market driven development strategy, the government simplified both the regulatory and policy environment, while government pursued privatization of public enterprises in some sectors and commercialization in others. However, in spite of significant privatization activities recorded, the World Bank Report of 1994 had concluded that government divesture of equity in public enterprises under privatization programme did little to decrease the size of government's portfolio in the economy. Thus, the impact of private investment on growth has been low and less significant in raising the level of output expansion. Apart from flawed government's policies, other factors that has inhibited the growth of private investment in Nigeria include poor infrastructure, high level of corruption at all levels of government, difficulties faced by private investors in obtaining loans in Nigeria, inefficiencies in the capital and money market and import dependent production structure. Literature identified three other factors that accounted for the low level of private investment in Nigeria: weak domestic demand, high costs of production and the different measures of uncertainties (political, social and 
economic). Since private investor's output compete with foreign and more improved products, consumers in Nigeria always have no choice between imported products and locally produced ones. This has reduced the market quota of domestic private investors.

The question that comes to mind is "what can explain the inherent weakness and stagnation of private investment in Nigeria? The objective of this paper is thus to develop a model for the investigation of the determinants of private investment in Nigeria and to empirically test the implications of changes in possible determinants of private investment. This is to enable us study the implications of possible shifts of government policy that placed emphasis on private sector as an engine of growth.

Other than this introductory section, the rest of the paper is divided into three sections. The second section is on literature review and the third section is made up of the statistical procedures. The last section concludes this paper.

\section{Literature Review}

Investment is broadly classified into four major components: the private domestic investment, public domestic investment and portfolio investment. Private domestic investment refers to gross fixed capital formation plus net changes in the level of inventories, whereas public investment includes investment by government and public enterprises on social and economic infrastructure, real estate and tangible assets (Bakare, 2011). The combination of both private and public investments is refereed to as gross fixed capital formation in order to distinguish them from their counterpart, foreign investment. When foreign investment is on tangible asset, it is referred to as direct foreign investment and called portfolio investment when it is on shares, bonds and securities. The major issue in policy formulation and implementation is how to use available resources-capital and natural resources to achieve economic development. In Nigeria, a good part of the resources is privately owned by numerous relatively small businesses who, acting independently, contribute to flexibility and entrepreneurship. It is therefore important for policy makers to be able to assess how private investment responds to changes in government policies. This could be through analyzing how private investment in the country is decided through the variables that systematically affect it (Moshi and Kilindo, 1999). Blejer and Khan (1984) developed a formal framework for studying the determinants of private investment in developing countries. This framework was an extension of past theoretical literature on investment which produced a unique class of models of the flexible accelerator type linked to Jorgenson (1967) and Hall (1977). Sundarajan and Thakur (1980) and Tun Wai and Wong (1982) incorporated features of the neoclassical model into investment models for developing countries. Their analysis take into perspective data problems and structural features that caused a discrepancy between the modern theory of investment and the models that were specified for developing countries. Blejer and Khan (1984) derived an explicit functional relationship between the principal policy investments and private capital formation and analyzed the extent of possible "crowding out". Blejer and Khan (1984a) found a positive relationship between the share of private investment in total investment and the ratio of total investment to income. They found in their study on private investment in developing countries that the bigger the share of private investment, the higher the average growth rate of the economy, highlighting the significance of private investment behaviour in developing countries. Balassa (1988) who studied public finance and economic development differed on his view since he found in his study of 30 countries that a negative relationship exists between private investment and public investment. Greene and Villanueva (1991) carried out an empirical study on private investment behaviour in 23 developing countries and found that investment in public physical infrastructure complemented private investment. Samuel (1996) used panel data to assess the investment decisions of 331 American manufacturing firms for the 1972/1990 period. He found that the principal determinant of investment was cash flow. Zeufack (1997) investigated the investment behavior of manufacturing firms in Cameroon between 1988 and 1992. He found that uncertainty has a negative influence on investment. Bamidele and Englana (1998) studied the relationship between macroeconomic environment and private investment behaviour in Nigeria. They discovered that the macroeconomic environment in Nigeria, political instability and poor infrastructure facilities are responsible factors for the higher cost of business transaction in Nigeria. Moshi (1999) studied government policy and private investment in Tanzania. The study showed that public investment on infrastructure exerted a positive and significant impact on private investment in Tanzania. Sene (2000) used a panel of 20 Senegalese firms between the period of 1988 and 1996 to examine the behaviour of private investment. The finding was that private investment is mostly influenced by demand fluctuations. Dipo and Philip (2008) in their assessment of private investment behaviour and trade policy in Nigeria found that macroeconomic uncertainty, measured by volatility of relative prices have impact on corporate investment in Nigeria. Patience and Osaro (2010) investigated the trade and dynamics of the determinants of investment in Nigeria. Using the cointegration technique, they found that past outcome of domestic investment strongly influence the present level of investment in Nigeria. They also found that market fundamentals do not encourage domestic investment. Olusegun (2010), in his assessment of the role of government in explaining 
domestic investment in Nigeria found from the long run estimation and impulse response that a well structured and stable socio-economic environment will boost domestic investment over the long run. Enang (2010) empirically assessed macroeconomic reforms, government size and investment behvaiour in Nigeria and found that government size did not complement private investment initiative and that credit to the private sector was a significant factor in stimulating private investment in Nigeria. Susthene (2010) studied the determinants of private investment in Benin using panel data and he noted that demand uncertainty and fluctuations in the imports of manufactured goods from Nigeria have a negative impact on investment by private firms in Benin. Babajide (2011) analyzed financial sector reforms and private investment in Sub-Saharan African countries. The result showed that financial sector reforms have a positive effect on private investment in the selected countries, thus offering support to the financial liberalization hypothesis. Bakare (2011) studied the determinants of private domestic investment in Nigeria, using cointegration technique with its implied Error Correction Mechanism. The study showed that the political crisis may have created a climate hostile to positive investment in Nigeria.

Thus, while various factors have been held responsible for the poor response of private domestic investment to economic performance, the extent of empirical research on this issue is still limited. In most cases, empirical studies either covered only a short period of time or used less sophisticated estimation technique. This study employs a more advanced econometric technique and the data covered a wider period, which included both the structural Adjustment Programme (SAP) and post SAP periods of inter temporal change in private investment behaviour in Nigeria. The study also captures the importance of the Real Effective Exchange Rate which has been neglected in previous model in influencing the behaviour of private investment in Nigeria. This will provide the true picture of the behaviour of private investment in Nigeria.

\section{Modeling private investment}

The conventional approach to time-series econometrics is based on the implicit assumption of stationarity of time-series data. A recent development in time-series econometrics has cast serious doubt on the conventional time-series assumptions. There is substantial evidence in the recent literature to suggest that many macroeconomic time series may possess unit roots. That is, they are non-stationary processes. A time-series integrated of order zero $\mathrm{I}(0)$, is level stationary, while a time-series integrated of order one, $\mathrm{I}(1)$, is stationary in first difference. Most commonly, series are found to be integrated of order one, or I(1). The implication of some systematic movements of integrated variables in the estimation process may yield spurious results. In the case of a small sample study, the risk of spurious regression is extremely high. In the presence of I(1) or higher order integrated variables, the conventional t-test of the regression coefficients generated by conventional OLS procedure is highly misleading (Granger and Newbold, 1977).

Resolving these problems requires transforming an integrated series into a stationary series by successive differencing of the series depending on the order of integration (Box and Jenkins, 1970). However, Sargan (1964), Hendry and Mizon (1978) and Davidson, Hendry, Sbra and Yeo (1978) have argued that the differencing process loses valuable long run information in data, especially in the specification of dynamic models. If some, or all, of the variables of a model are of the same order of integration, following the Engle-Granger theorem, the series are cointegrated and the appropriate procedure to estimate the model will be an error correction specification. Hendry (1986) supported this view, arguing that error correction formulation minimizes the possibilities of spurious relationships being estimated as it retains level information in a non-integrated form (Hendry, 1986). Davidson, Hendry, Sbra and Yeo. (1978) proposed a general autoregressive distributed lag model with a lagged dependent variable, which is known as the 'error-correction' term. Davidson, Hendry, Sbra and Yeo (1978) also advocated the process of adding lagged dependent and independent variables up to the point where residual whiteness is ensured in a dynamic specification. Therefore, error correction models avoid the spurious regression relationships.

To guard against the possibility of estimating spurious relationships in the presence of some nonstationary variables, estimation is performed using a general-to-specific Hendry-type error correction modelling (ECM) procedure. This procedure begins with an over-parameterised autoregressive distributed lag (ADL) specification of an appropriate lag. The consideration of the available degrees of freedom and type of data determine the decision on lag length. With annual data, one or two lags would be long enough, while with quarterly data a maximum lag of four can be taken. Under this ECM procedure, the long run relationship is embedded within the dynamic specification.

The most important concern of the paper is to quantify the factors that influence the behaviour of private investment in Nigeria. Blejer and Khan (1984) analyzed the relationship between the principal policy instruments and capital formation. The instrument to be linked to private investment in Nigeria thus include: government size, Real Effective Exchange Rate, credit to the private sector, inflation rate and interest rate. 
The model is specified below:

$$
\text { LPINV }=b_{o}+b_{1} \text { LREER }+b_{2} \text { LINTR }+b_{3} \text { LGOVSIZE }+b_{4} \text { INF }+ \text { Ut }
$$

Where: $U t$ is the error term and $u_{t}$ is the error term. $b_{1}$ to $b_{3}$ represents the various parameters

\section{Variables Description}

\section{PINV}

Private investment, which is composed of all domestic investment in Nigeria. It excludes foreign direct investment

\section{INTR}

Interest rate, this is the commercial bank lending rate to private investors

\section{REER}

Real Effective Exchange Rate, which is the Nominal Effective Exchange Rate deflated by price level differentials. It is also serves as a measure of the international competitiveness of Nigeria.

\section{GOVSIZE}

Government size proxied by the ratio of government spending to Gross Domestic Product.

\section{INF}

Inflation rate, this is used to capture the general price level.

A positive relationship is expected between government size and private investment. Thus, an expansion of government size is expected to have a positive impact on the level of private investment. An increase in the level of economic growth is an indication of an increase in real income and hence aggregate demand. An expansion of aggregate demand has the potential of increasing the level of private investment. High rate of inflation and high interest rate are expected to reduce the level of private investment. The impact of the Real Effective Exchange Rate on private investment is expected to be positive, all things being equal since a depreciation of the real value of the naira increases the competitiveness of the products of private investment abroad.

\section{Sources of Data}

The data where collected from the Central bank of Nigeria Statistical Bulletin, 2011 and various Issues of the World Bank Indicators for Nigeria. The data on government size was computed by the authors. The data are shown in appendix table one and figure 2 in the appendix shows the trend in the variables

\section{Unit Root test}

The analysis commenced with the unit root test which is used to test whether the variables are stationary or not and their other of integration. The summary of the Augmented Dickey Fuller (ADF) unit root test and the Philips Perron (PP) tests are shown in table1:

Table 1. Summary of ADF and PP Unit Root Test Results

\begin{tabular}{lllllll}
\hline Variables & ADF & \multicolumn{5}{l}{ PP } \\
\hline PINV & -2.55 & $-6.20^{*}$ & $\mathrm{I}(1)$ & -2.04 & $-3.68^{*}$ & $\mathrm{I}(1)$ \\
INTR & -2.20 & -5.73 & $\mathrm{I}(1)$ & -2.54 & $-7.61^{*}$ & $\mathrm{I}(1)$ \\
REER & -1.75 & -4.11 & $\mathrm{I}(1)$ & -2.40 & $-4.39^{*}$ & $\mathrm{I}(1)$ \\
INF & $-3.01^{* *}$ & -5.17 & $\mathrm{I}(\mathrm{O})$ & $-2.75^{* * *}$ & -5.42 & $\mathrm{I}(0)$ \\
GOVSIZE & $-3.89^{*}$ & -6.24 & $\mathrm{I}(\mathrm{O})$ & $-5.88^{*}$ & -11.89 & $\mathrm{I}(\mathrm{O})$ \\
\hline
\end{tabular}

NB: $\quad * \quad$ Indicates stationary at the 1 percent level

** Indicates stationary at the 5 percent level

*** Indicates stationary at the 10 percent level

The results of both the ADF and PP unit root test show that the private investment, interest rate and Real Effective Exchange Rate were non stationary. They however became stationary after the first differences were taken. Inflation rate and government size were stationary at the level. This is probably because inflation rate is in percentage and government size is in ratio. However, following Harris (1995) and Gujarrati (2003), both I(1) and I(0) variables can be tested for cointegration, which forms the next stage of the analysis.

\section{Cointegration test}

Since most of the time series variables are I(1), the use of traditional econometric technique such as the $t$ and $F$ statistics can produce biased and misleading results. The regression may generate results with good diagnostic 
statistics, but spurious in real sense. Since both the ADF and PP unit root tests suggest that the variables are integrated of various orders, both I(1) and $\mathrm{I}(0)$, a linear combination of the various subsets of the variables under consideration may be cointegrated. To assess this, we proceed to carry out further test using the Johansen cointegration technique. The Johansen cointegration technique has advantages over the Engel-Granger test because amongst others, it allows the existence of cointegration between systems of variables without any bias on the estimates because it is not arbitrary. It allows for more than one cointegrating vector unlike the Engel-Granger test and can also estimate a long run relationship between or among non-stationary variables. The result of the Johansen cointegration test is shown in table 2:

Table 2. Summary of Johansen cointegration test result

\begin{tabular}{|c|c|c|c|c|}
\hline $\begin{array}{l}\text { Hypothesized No. } \\
\text { of CE(s) }\end{array}$ & Eigenvalue & $\begin{array}{l}\text { Trace } \\
\text { Statistic }\end{array}$ & $\begin{array}{l}5 \text { percent } \\
\text { critical value }\end{array}$ & $\begin{array}{l}1 \text { percent } \\
\text { critical value }\end{array}$ \\
\hline None** & 0.79 & 122.81 & 68.52 & 76.07 \\
\hline At most $1 * *$ & 0.65 & 79.50 & 47.21 & 54.46 \\
\hline At most $2 * *$ & 0.60 & 50.44 & 29.68 & 35.65 \\
\hline At most $3 * *$ & 0.45 & 24.97 & 15.41 & 20.04 \\
\hline At most $4 * *$ & 0.26 & 8.42 & 3.76 & 6.65 \\
\hline $\begin{array}{l}\text { Hypothesized No. } \\
\text { of CE(s) }\end{array}$ & Eigenvalue & $\begin{array}{l}\text { Max-Eigen } \\
\text { Statistic }\end{array}$ & $\begin{array}{l}5 \text { percent } \\
\text { critical value }\end{array}$ & $\begin{array}{l}1 \text { percent } \\
\text { critical value }\end{array}$ \\
\hline None** & 0.79 & 43.31 & 33.46 & 38.77 \\
\hline At most $1^{*}$ & 0.65 & 29.06 & 27.07 & 32.24 \\
\hline At most $2 *$ & 0.60 & 25.47 & 20.97 & 25.52 \\
\hline At most $3^{*}$ & 0.45 & 16.54 & 14.07 & 18.63 \\
\hline At most $4 * *$ & 0.26 & 8.42 & 3.76 & 6.65 \\
\hline
\end{tabular}

The trace statistic and max-eigen statistic indicate the existence of 5 cointegration rank among the variables. This indicates the existence of cointegration in the time series variables suggesting that normalized cointegration coefficient gives the long run relationship among the variables. The existence of at least 1 cointegrating equation makes it possible to estimate the overparameterize and the parsimonious Error Correction Mechanism (ECM).

\section{Overparameterize and Parsimonious ECM Models}

Overparameterize and parsimonious ECM provide a solution to the problem of spurious or non-sense regression associated with estimating models involving time series variables and also to reflect the dynamic adjustment to the long run (Patterson, 1990). Thus, we adopted the general to specific framework. The uniqueness of ECM is that it provides the framework for establishing the link between the long and short run approaches to economic modeling (Enang, 2010). With the ECM, no first difference information is lost because the ECM incorporates both the short run dynamics and long run information in the error correction term. Table 3 shows the result of the overparameterize ECM:

Table 3. Summary of Overparameterize ECM. Modeling DLPINV

\begin{tabular}{lllll}
\hline Variables & Coefficient & Standard error & t-statistic & Prob \\
\hline DLINTR & -1.06 & 0.11 & -9.87 & 0.0000 \\
DLINTR(-1) & -3.04 & 2.48 & -1.23 & 0.2395 \\
DLINTR(-2) & 3.19 & 2.40 & 1.33 & 0.2053 \\
DLREER & -0.87 & 0.08 & 10.38 & 0.0000 \\
DLREER(-1) & 2.63 & 1.44 & 1.83 & 0.0893 \\
DLREER(-2) & -1.40 & 1.34 & -1.04 & 0.3163 \\
GOVZIZE & 0.93 & 0.15 & 6.05 & 0.0000 \\
GOVSIZE(-1) & -0.04 & 0.05 & -0.78 & 0.4500 \\
GOVSIZE(-2) & -0.03 & 0.06 & -0.46 & 0.6546 \\
INF & 0.03 & 0.05 & 0.57 & 0.5759 \\
INF(-1) & -0.08 & 0.04 & -1.85 & 0.0860 \\
INF(-2) & -0.01 & -0.01 & -2.22 & 0.0346 \\
ECM(-1) & -0.41 & 0.14 & -3.02 & 0.0047 \\
C & -0.20 & 0.69 & -0.29 & 0.7789 \\
\hline
\end{tabular}

$\mathrm{R}^{2}=0.65, \mathrm{AIC}=4.35, \mathrm{SC}=5.01, \mathrm{LL}=-46.89$, Statistic $=32.07, \mathrm{DW}=2.03$

The above table also includes the one period lagged value of the ECM whose coefficient is negative and statistically significant to support the existence of cointegration. 
Table 4 shows the results of the parsimonious (preferred) ECM result:

Table 4. Summary of Parsimonious ECM. Modeling DLPINV

\begin{tabular}{lllll}
\hline Variables & Coefficient & Standard error & t-statistic & Prob \\
\hline DLINTR & -0.42 & 0.14 & -3.02 & 0.0047 \\
DLREER & 0.61 & 0.11 & 5.39 & 0.0000 \\
DLREER(-1) & 0.73 & 0.14 & 5.39 & 0.0000 \\
GOVSIZE & 0.32 & 0.16 & 2.00 & 0.0526 \\
INF(-2) & -0.46 & 0.22 & -2.14 & 0.0412 \\
ECM(-1) & -0.56 & 0.25 & -2.26 & 0.0323 \\
C & 0.104823 & 0.87 & 0.12 & 0.9048 \\
\hline
\end{tabular}

$\mathrm{R}^{2}=0.76, \mathrm{AIC}=-4.78, \mathrm{SC}=-5.16, \mathrm{LL}=-61.37$, FStatistic $=40.57, \mathrm{DW}=2.12$

The parsimonious ECM result was gotten by deleting the insignificant variables from the overparameterize ECM. The Akaike Information criterion, Schwarz criterion and log-likelihood were used to select the appropriate lag-length. The parsimonious result indicates that interest rate, Real Effective Exchange Rate, government size and inflation rate are statistically significant in explaining the behaviour of private investment in Nigeria, particularly during the period under consideration. Some are significant at their levels or current value, while others were significant at the lag. This is an indication that economic agents in Nigeria are not only concerned about current economic environment, but also in the past behaviour in making investment decisions. The coefficient of interest rate is statistically significant and has the right sign. This is an indication that a reduction in interest rate reduces the costs of capital which is good for private investment as it leads to increase in the profits of private investors. The statistical significance of the Real Effective Exchange Rate which is positively signed is an indication that the international competitiveness through export expansion is necessary in generating the desired level of private investment in Nigeria. Thus, a devaluation of the Real Effective Exchange Rate by 1 percent increased the level of private investment by 73 percent. The statistical significance of government size variable in influencing the behaviour of private investment in Nigeria provides some justifications for the large government expenditure over the past thirty years in capital project to improve private investment. The statistical significance of inflation rate which has a negative sign is an indication that the increasing level of domestic prices in Nigeria has been detrimental to the growth of private investment in Nigeria. The statistical significance of the error term with the correct negative sign indicates a well-behaved (specified) error correction model which is symptomatic of how agents adjust their anticipated changes in private investment, which is about 56 percent on the average. This is an indication that about 56 percent of the disequilibrium in private investment is corrected each year. This supports the existence of a satisfactory speed of adjustment. Since the distribution of the error term is stationary, the combinations of dependent and independent variables are cointegrated (Engel and Granger, 1987).

Table 5 shows the result of the diagnostic test:

Table 5. Diagnostic Statistics

\begin{tabular}{|l|l|}
\hline Jarque-Bera 1.827 & Probability: 0.872 \\
\hline White Heteroskedasticity \\
\hline F statistic 1.627 & Probability 0.662 \\
\hline Breusch Godfrey \\
\hline Fstatistic 2.265 & Probability 0.762 \\
\hline
\end{tabular}

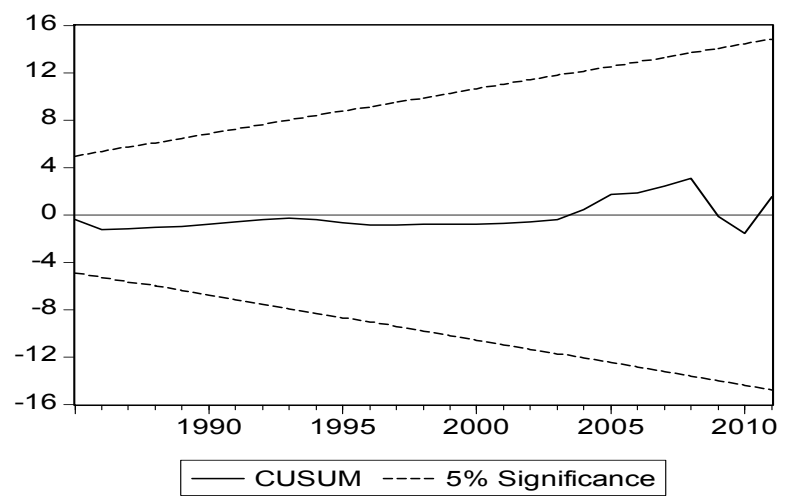

Figure 1. CUSUM Stability test 
The result shows an acceptance of the null hypothesis that the errors are homoskedastic, as shown by the White hetereroskedasticity test. The Jarque-Bera normality test indicates an acceptance of the null hypothesis that the errors are normally distributed. This is an indication that the results are unbiased, has minimum variance, are consistent and follows a normal distribution. The Cumulative Sum of Squares (CUSUM) in figure 1 above indicates that the model is stable. This is because the CUSUM line fall in-between the two $5 \%$ percent lines.

\section{Conclusion}

This paper has attempted to develop a model for investigating the behaviour of private investment in Nigeria. The result show that the competitiveness of Nigeria in the international community is linked to the behaviour of private investment in Nigeria. The significance of government size provides justification for the huge money spent by government in generating the desired infrastructure so as to improve private investment in Nigeria. This also indicate the existence of good service delivery and good expenditure pattern. The negatively signed inflation rate is an indication of the detrimental impact of high prices on private investment in Nigeria. The negatively signed and significant interest rate is an indication that reduced interest rate increase the profit of private investors in Nigeria. The co integration test shows a long run relationship among the variables which is complemented by the negatively signed and significant error term. It is thus recommended that the government should do more to tackle the problem of high inflation rate which has been detrimental to the development of private investment in Nigeria. The government should further lower the interest rate to private investors as this will further increase their turnover. More should also be done to improve the performance of private investors through enhanced international competitiveness of the Nigerian economy via further devaluation of the naira.

\section{References}

Babajide, F. (2011). Financial sector reforms and private investment in Sub-Saharan African countries. Journal of Economic Development, 36(3).

Bakare, A.S. (2011). The determinants of private domestic investment in Nigeria. Far East Journal of Psychology and Business, 4(2), August.

Balassa, B. (1988). Public finance and economic development. PPR Working Paper, 1. World Bank, Washington, D.C.

Bamidele, A. \& Englana, A. (1998). Macroeconomic environment, investment stimulation and economic growth and development: The Nigerian experience. Rethinking Investment for Economic Development in Nigeria: Proceedings of the Annual Conference of the Nigerian Economic Society: 75-101.

Blejer, M.I. \& Khan, M.S. (1984b). Government policy and private investment in developing countries. IMF Staff Papers, 31(2): 379403.

Box, G.E.P. \& G. M. Jenkins, (1970). Time Series Analysis, Forecasting and Control, San Francisco: Holden-Day.

Davidson, J., Hendry, D., Sbra, F. \& Yeo, S. (1978). Econometric modelling of the aggregate time series relationship between consumers' expenditure and income in the United Kingdom, Economic Journal, 88(352): 661 - 92. http://dx.doi.org/10.2307/2231972

Dipo, T.B. \& Phillip, C.O. (2008). Private investment behaviour and trade policy practice in Nigeria. AERC Research Paper, 77, Nairobi.

Enang, B.U. (2010). Macroeconomic reforms, government size and investment $\quad$ behaviour $\quad$ in Nigeria: An empirical investigation. Journal of Sustainable Development in Africa, 12(1).

Engle, R.I. \& Granger, C.W. (1987). Cointegration and error correction: Representation, estimation and testing. Econometrica, 55(2): 251-276. http://dx.doi.org/10.2307/1913236

Hall, R.E. (1977). Investment, interest rates and the effects of stabilization policies. Brookings Papers on Economic Activity, 2(103), The Brookings Institution.

Harris, R. (1995). Using Cointegration Analysis in Econometric Modeling. London: Prentice Hall.

Hendry, D.F. (1986). Econometric modelling with cointegrated variables: An Overview, Oxford Bulletin of Economic and Statistics, 48(3): 201-12. http://dx.doi.org/10.1111/j.1468-0084.1986.mp48003001.x

Hendry, D.F. \& Mizon, G., (1978). Serial correlation as a convenient simplification, not a nuisance: A comment on a study of the demand for money of the Bank of England, Economic Journal, 88(351): 549 - 63. http://dx.doi.org/10.2307/2232053 
Granger, C.W. \& Newbold, P. (1977). The time series approach to econometric model building, In Obadan, M.I. and Iyoha, M.A. eds. (1996). Macroeconomic Analysis: Tools, Techniques and Applications. NCEMA, Ibadan: Polygraphics Venture Ltd.

Greene, J. \& Villanueva, D. (1991). Private investment in developing countries: An empirical analysis IMF Staff Papers, 38(1). http://dx.doi.org/10.2307/3867034

Gujarati, D. N. (2003). Basic Econometrics (4e). New York: McGraw-Hill Inc.

Ishola, R.F. (2008). Optimizing macroeconomic investment decisions: A lesson from Nigeria. European Journal of Scientific Research, 22(4): 469-470.

Jorgenson, D.W. (1967). The theory of investment behaviour in Ferber, R. ed., Determinants of Investment Behaviour, New York: national Bureau of Economic Research.

Moshi, H.P.B. (1999). The impact of investment policy on macroeconomic variables: A case study of private investment in Tanzania. AERC Research Paper, 89, Nairobi.

Moshi, H.P.B. \& Kilindo, A.A.L. (1999). The impact of government policy on macroeconomic variables: A case study of Private investment in Tanzania. AERC Research Paper, 89, Nairobi.

Olusegun, A.A. (2010). Role of government in explaining domestic investment in Nigeria. University of Pretoria Working Paper, 168.

Patience, D. \& Osaro, O.A. (2010). The trends and dynamics of the determinants of investment in Nigeria. International Review of Business Research Papers, 6(6) December. 159-163.

Patterson, K. (1990). An Introduction to Applied Econometrics. New York: Palgrave publishing.

Samuel, C. (1996). The investment decision: A re-examination of theories using panel data. World Bank Policy Research Working Paper, 1656. The World Bank, Washington, D.C.

Sargan, J.D. (1964). Wages and prices in the UK: A study in econometric methodology, in P. Hart, G. Mills and J. Whittaker (eds.), Econometric Analysis for National Planning, London: Butterworths.

Sene, M. (2000). Les facteurs exlicatifs de I. Investissement prive. Des cas des nterprises senegalaises, Post-ma Thesis, Universite, Cheith Anta, Diop de Daker.

Sosthene, U.G. (2010). The determinants of private investment in Benin: A panel data analysis. AERC Research Paper, December.

Sundarajan, V. \& Thakur, S. (1980). Public investment, crowding out and growth: A dynamic model applied to India and Korea. IMF Staff Papers, 22(8):14-55.

Tun Wai, U. \& Wong, C. (1982). Determinants of private investment in developing ountries. Journal of Development Studies, $19: 10-36$.

Zenfack, A.G. (1997). Structure de propriete et compertement d' investment en nvironment incertia: estimation sur dunness de panel du sector manufacturier amerounais. Revue d' economic du development, 1: 2959. 


\section{Appendix Table1}

\begin{tabular}{|c|c|c|c|c|}
\hline Years & GOVSIZE & INF & INTR & PINV \\
\hline 1980 & 0.02 & 16.6 & 6 & 467 \\
\hline 1981 & 0.16 & 11.8 & 6 & 137.8 \\
\hline 1982 & 0.31 & 9.9 & 8 & 1624.9 \\
\hline 1983 & 0.21 & 20.9 & 8 & 556.7 \\
\hline 1984 & 0.20 & 7.7 & 10 & 534.8 \\
\hline 1985 & 0.14 & 23.2 & 10 & 329.7 \\
\hline 1986 & 0.14 & 39.5 & 10 & 2499.6 \\
\hline 1987 & 0.12 & 5.5 & 12.75 & 680 \\
\hline 1988 & 0.12 & 5.4 & 12.75 & 1345.6 \\
\hline 1989 & 0.10 & 10.2 & 18.5 & 439.4 \\
\hline 1990 & 0.10 & 38.2 & 18.5 & 464.3 \\
\hline 1991 & 0.13 & 40.9 & 14.5 & 1808 \\
\hline 1992 & 0.11 & 7.5 & 17.5 & 8269.2 \\
\hline 1993 & 0.10 & 13 & 26 & 32994.4 \\
\hline 1994 & 0.10 & 44.5 & 13.5 & 3907.2 \\
\hline 1995 & 0.01 & 57.2 & 13.5 & 48677 \\
\hline 1996 & 0.06 & 57 & 13.5 & 2731 \\
\hline 1997 & 0.09 & 72.8 & 13.5 & 5731 \\
\hline 1998 & 1.25 & 29.3 & 14.31 & 24078.9 \\
\hline 1999 & 0.13 & 8.5 & 18 & 1779.1 \\
\hline 2000 & 0.11 & 10 & 13.5 & 3347 \\
\hline 2001 & 0.20 & 6.6 & 14.3 & 3377 \\
\hline 2002 & 0.10 & 6.9 & 19 & 8206.8 \\
\hline 2003 & 0.12 & 18.9 & 15.7 & 13056.1 \\
\hline 2004 & 0.09 & 12.9 & 15 & 199908.7 \\
\hline 2005 & 0.08 & 14 & 13 & 25881.3 \\
\hline 2006 & 0.77 & 15 & 12.25 & 41470.8 \\
\hline 2007 & 0.09 & 17.9 & 8.75 & 56654 \\
\hline 2008 & 0.08 & 8.2 & 9.81 & 62964.7 \\
\hline 2009 & 0.10 & 5.4 & 7.44 & 69902.1 \\
\hline 2010 & 0.11 & 11.6 & 8.6 & 74826.8 \\
\hline 2011 & 0.09 & 12.4 & 9.3 & 77468.2 \\
\hline
\end{tabular}

Sources:

1. Central Bank of Nigeria Statistical Bulletin, various years

2. World Bank Indicators for Nigeria, Various issues

3. Authors computation 

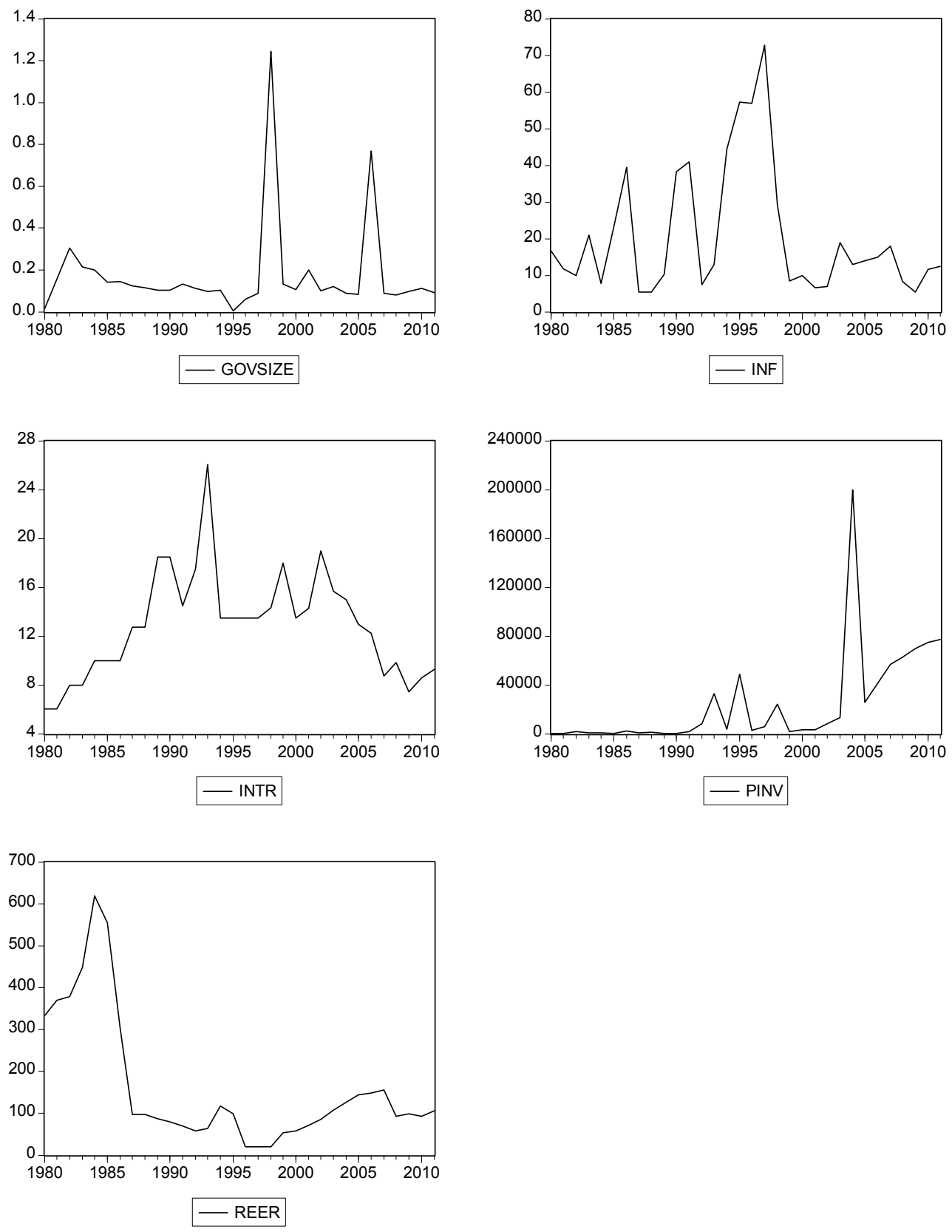

Figure 2. Trends in the table 